\title{
Islamic Populism and Political Parties: \\ PPP Electoral Failure in the Middle of the Islamic Populism Movement in the 2019 Election
}

\author{
Rexsy Pangestu ${ }^{*}$ and Rusydan Fathy ${ }^{2}$ \\ ${ }^{1}$ Cultural Society Research Center, \\ ${ }^{2}$ National Innovation Research Innovation Research Agency \\ *Email: rexsy.pangestu@gmail.com
}

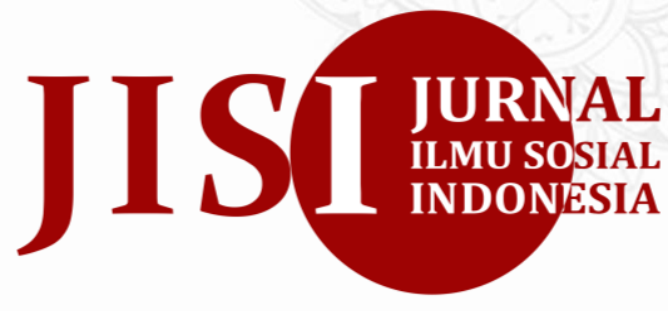

p-ISSN: 2808-9529 (Printed) e-ISSN: 2808-8816 (Online)

Jurnal Ilmu Sosial Indonesia (JISI)

VOL. 2, NO. 1 (2021)

Page: 1 - 13

Recommended Citation:

Pangestu, R., \& Fathy, R. (2021). Islamic Populism and Political Parties: PPP Electoral Failure in the Middle of the Islamic Populism Movement in the 2019 Election. Jurnal Ilmu

Sosial Indonesia (JISI), 2(1), 1-13. doi:https://doi.org/10.15408/jisi.v2i1.24886

Available at:

http://journal.uinjkt.ac.id/index.php/jisi/arti cle/view/24886

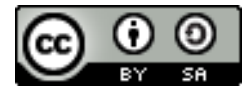

This is an open access article under CC-BY-SA license (C) Copyright Attribution-Share Alike 4.0 International (CC BY-SA 4.0)
Abstract. This study discusses the decline in the vote acquisition of Partai Persatuan Pembangunan (PPP) in the midst of the Islamic populism movement in the 2019 Election. As an Islamic party, this momentum should be a turning point for PPP to become a party that listens to the aspirations or interests of Muslims, as one of the task of political parties in a democratic country is as an aggregation of interests. This study uses qualitative research methods with primary data from interviews and secondary data from library studies. Based on the reading of these data, it can be seen that the failure of PPP to gain vote incentives from the Islamic populism movement in the 2019 elections is; first, the failure to create a good institutional system. This poor institutionalization is reflected in the PPP's internal conflicts. Second, there is a split in the political orientation of Indonesian Muslims in conservatism and moderatism which is clearly depicted in the 2019 election. Third, there is a change in the political orientation of the Indonesian Islamic community which places religion not as the only foothold in their political choices. People choose political parties not based on who is the most Islamic, pious, or representing the aspirations of Muslims, but based on the performance and work programs offered by the party.

Keywords: PPP, Islamic Populism, 2019 Election, Party Institutionalization.

\begin{abstract}
Abstrak. Penelitian ini membahas perihal panurunan perolehan suara Partai Persatuan Pembangunan (PPP) di tengah gerakan populisme Islam pada Pemilu 2019. Harusnya sebagai partai Islam momentum ini adalah titik balik bagi PPP untuk bisa menjadi partai yang mendengar aspirasi atau kepentingan umat Islam, sebagaimana salah satu tugas partai politik dalam negara demokrasi yakni sebagai agregasi kepentingan. Penelitian ini menggunakan metode penelitian kualitatif dengan data primer dari hasil wawancara dan data sekunder dari hasil kajian Pustaka. Berdasarkan pembacaan terhadap data-data tersebut terlihat bahwa kegagalan PPP meraih insentif suara dari gerakan populisme Islam pada Pemilu 2019 adalah; pertama, kegagalan menciptakan sistem kelembagaan yang baik. Kelembagaan yang tidak baik ini tergambar dari konflik internal PPP. Kedua, adanya keterbelahan orientasi politik umat Islam Indonesia dalam konservatisme dan moderatisme yang tergambar kuat dalam Pemilu 2019. Ketiga, adanya perubahan orientasi politik masyarakat Islam Indonesia yang menempatkan agama bukan sebagai pijakan satu-satunya dalam pilihan politiknya. Masyarakat memilih partai politik bukan berdasarkan siapa yang paling Islam, salih, atau mewakili aspirasi umat Islam, namun berdasarkan kinerja dan program kerja yang ditawarkan partai.
\end{abstract}

Kata Kunci: PPP, Populisme Islam, Pemilu 2019, Pelembagaan Partai Politik. 


\section{INTRODUCTION}

This study discusses the failure of Partai Persatuan Pembangunan (PPP) in obtaining a voice base for Islamic populism in the 2019 elections. In the past five years, the discourse of Islamic political movements has become very popular in Indonesian society. One of the examples of this political movement is the mass action of Muslims taking to the streets known as the "Aksi Bela Islam". This movement has practically taken action seven times, including the first on October 14, 2016 (Republika.co.id, 2019).

This first movement demanded an immediate investigation and sent a criminal sentence to the former Governor of DKI Jakarta Basuki Tjahaja Purnama for the alleged blasphemy case during a visit to Pramuka Island regarding his statement on the surah al-Maidah verse 51 . With the same demands this movement was carried out again on November 4, 2016, known as Aksi Bela Islam II or Action for Peace 411,1 then December 2, 2016 known as Aksi Defending Islam III, ${ }^{2}$ Action for Defending Islam IV on February 11, 2017, ${ }^{3}$ Action to Defend Islam V or Action 212 volume II, Action to Defend Islam VI on March 31, 2017, and Action to Defend Islam VII on May 5, 2017.

Until then this case was processed in court and Ahok was named a suspect, this movement continued as a form of political Islam seen before and after the moment of the 2017 DKI Pilkada and also before the 2019 Election. Then if we look at some of the mass action movements above, there is one phenomenal one where movements that can attract Muslim participation take action with a total of approximately three million people. This movement is known as the "212 movement", which also formed a forum for the participants under the name "212 alumni". This forum has many different backgrounds of Islamic organizations, which means it is successful as a forum for Islamic political aspirations, although officially Muhammadiyah and

1 This action was carried out in front of the Palace, the crowd asked to be given access to meet with President Jokowi. However, this could not be fulfilled and representatives from this action were given the opportunity to meet the Coordinating Minister for Political, Legal and Security Affairs Wiranto and Vice President Jusuf Kalla.

2 In addition to holding actions, this movement carries out joint Friday prayers, the center being at the National Monument (Monas), to the HI Roundabout, Tugu Tani, and Juanda Station. The number of participants who attended this movement was approximately three million people

3 This action was carried out at the Istiqlal Mosque, apart from guarding the initial demands, it also carried out joint prayer and tausiyah activities from several scholars. The Islamic Community Forum (FUI) and the National Movement to Guard the Fatwa of the Indonesian Ulema Council (GNPF-MUI) are the coordinators of this activity.
$\mathrm{NU}$ as Islamic organizations in Indonesia do not support this existence, but there are still communities from each organization in this movement. (Octavia, 2017). Furthermore, at the moment of the 2017 DKI election, this movement increasingly showed its strength when it was seen from the actors in it such as Habib Rizieq Shihab preaching and his campaign forbidding Muslims from choosing infidel leaders. The narrative shows political divisions among the people of DKI about "who is Muslim" and "who is infidel".

In addition to the narrative about religious identity, this issue is added to the narrative of populism. Quoting the opinion of Vedi R. Hadiz, what is meant by populism is the accumulation of all the disappointments of the people (who are Muslim) to the government, plus the economic disappointment in which Islam as the identity of the majority of interests is sidelined. (Adela, 2019). Then in the announcement of the results of the Jakarta election, the candidate pair Agus Harimurti Yudhoyono-Sylviana Murni received a percentage of $17.02 \%$, the pair Basuki Tjahaya Purnama-Djarot Syaiful Hidayat received $42.99 \%$, and Anies Baswedan-Sandiaga Uno $39.95 \%$ in the second round. first. Because from the results of the first round, no candidate pair has touched the 50\% percentage. The regional elections continued towards the second round where the results were won by the Anies-Sandi pair with a percentage of 57.96\% and Basuki Tjahaya Purnama-Djarot Syaiful Hidayat $42.04 \%$. These results make it clear that the narrative called Islamic populism has an effective power to gain a voice base. (Adela, 2019).

The momentum of this Islamic populism political movement should be a positive signal for Islamic political parties in the 2019 elections such as the United Development Party (PPP), the National Awakening Party (PKB), the National Mandate Party (PAN), and the Prosperous Justice Party (PKS) to gain votes. more than the 2014 election and as a political accommodation for Muslims. However, there is something interesting about the 2019 election results, instead of being able to increase the number of votes in the midst of the popularity of the narrative or Islamic populism movement, one of the Islamic parties, namely PPP, experienced a decrease in the number of votes from $6.63 \%$ in 2014 to $4.52 \%$. in 2019. Whereas other Islamic parties such as PKB tended to get a slight increase in votes at 9.04\% to $9.69 \%$. Then PKS experienced a significant increase from $6.79 \%$ to $8.21 \%$. (KPU, 2019). Referring to the previous statement, as a basis for research analysis on the failure of PPP as a political accommodation of Islamic populism. Researchers will use the theory of Islamic populism, the theory of party institutionalism, and the concept of Political Parties, and Elections in the discussion in this study. 
Populism itself is a form of identity study in political science which has many meanings that cannot be defined in a final way. For example, referring to one of the political scientists, Francis Fukuyama also admits that populism has many meanings. However, he explained populism as a form of politician's leadership style to gain popular support which is divided into three. The first is economic populism, namely leaders who promote popular economic policies. For example, Venezuela under Hugo Chavez, made a policy of opening an eye clinic and free food. (Fukuyama, 2019). Then another understanding of populism, especially related to this research is the view of Vedi R Hadiz in his work entitled Islamic Populism in Indonesia and The Middle East that populism is a social mobilization movement whose base is a combination or coalition of various classes that are not the same but have an same politics agenda (Hadiz, 2016).

Then according to Wasisto Rahardjo Jati, populism is an alternative way used to reromanticize the meaning of the people as "demos"; holder of the highest power above the trias politica institution. The romanticization of the meaning of "demos" has become an important weapon to bring back the substantive values of democracy into government practice. However, on the other hand, populism simultaneously reduces democracy because it aims to bend the constitutional channel by ignoring many procedures and stages that must be passed. This gave birth to negative results for the running of a country's democracy with distrust of public institutions which indicated that there was a problem with the credibility of public relations with the state. This illustrates that the populist movement in the middle class is like two sides of the same sword: repressive action or curative action (Wasisto Rahardjo Jati, 2017).

Then the Islamic populism that developed recently is the result of disillusionment with democracy. If conventional populism has a curative goal (healing) and construction for the democratic process that occurs so that there is a situation of sensitivity to the demands and aspirations of the wider community, Islamic populism that occurs explains different developments. First, "ummah" is a word used as a weapon to attract demos (people) who exclusively fight for the interests of Muslims. Second, it is advisable to support the democratic process as an effort to form a government, but on the other hand it is inclined to support a theocratic government system such as a caliphate or sharia government which is essentially towards prosperity (darul salam). Third, Islamic populism tends to prioritize aspects of identity strengthening based on symbols of religiosity (Wasisto Rahardjo Jati, 2017).
Then in this study using the theory of Islamic populism from Wasisto Rahardjo Jati to explain the object of research. Islamic populism in question refers to Islamic groups that took part in the "Action for Defending Islam" activities. Then when referring to the organization that drives the action, what is meant by Islamic populism is the Movement for the Guards of the Ulama Fatwa (GNPF). Then to explain that there has been a polarization of Islamic populism or Islamic groups. The author adds to the study literature on the relationship between religion and politics in Indonesia, which has a relationship with the fragmentation of people's political attitudes towards parties through religious differences with the term "stream" or group. Religious differences also explain the social and political organizations based on these differences.

Furthermore, institutionalization (institutionalization) is the process by which the organization becomes established. In political discussion, institutionalization is characterized by the stability of political actors in an organization and has a clear goal. In Huntington's opinion, institutionalization is the process by which the value and stability of organizations and procedures are obtained. Then the institutionalized party system is a system in which actors provide expectations and behaviors that are motivated by the conditions and rules of party competition that have been running for quite a long time (Crotty, 2018).

Then according to Mainwaring and Scully's view in their book entitled Building Democratic Institutions: Party System in Latin America, they explain that there are four dimensions of party system institutionalization. First, the existence of a stable pattern of party competition is one sign of a more institutionalized party system. This can be measured more systematically by comparing election volatility, which is a reference to changes in voter turnout from one election to the next. The volatility score illustrates the conceptual advantage of institutionalization as continuous.

Second, the relationship of attachment between the community and political parties, which is marked by self-identification in the majority of the community to certain parties or the existence of strong party roots in society which then forms an orderly pattern of competition stability between parties is an illustration of a strong institutional system. According to this theory, voters will choose a party based on ideological preferences or the party's work program. Then if voters choose based on the personality characteristics of the candidate, without program content or ideology, it is a sign of weak institutions (Crotty, 2018).

Third, political actors see parties as an important part of democratic politics and also follow party legitimacy. Therefore, even though they 
have a critical attitude towards certain parties and show an attitude of skepticism, legitimacy has an impact on the process of party system stability which is also part of institutionalization (Crotty, 2018).

Fourth, political parties or organizations are not subject to a handful of ambitious leaders. They have their own independence and value. This is where the institutionalization process takes place. On the other hand, if the party tends to be personalistic, what is depicted is a weak and fluid institutional system (Crotty, 2018). The low level of party institutionalization or weak institutionalization is indicated by, among others, the irregular pattern of party competition, weak party roots, lack of legitimacy given by the party, weak party organization, often dominated by personalistic leaders (Crotty, 2018).

\section{METHOD}

This is qualitative research. Referring to Lexy J. Moleong's opinion, (Moleong, 2018) qualitative research produces analytical methods and not statistical data like quantitative research. Qualitative research produces descriptive data, therefore, the main discussion in this study is to discuss the theory of Islamic populism and the failure of PPP as an accommodation for Islamic politics in the 2019 Election.

The data collected through literature study and interviews. Regarding the literature study, the researcher collects relevant data from electronic and printed media, such as books, journals, theses, theses, dissertations. For interviews, this research conducted interviews with people involved in the PPP central management. The results were obtained based on the sources that the researchers had from observations and interviews. It begins with grouping the data based on the types and characteristics. Then, carry out the analysis process. There are two sources of data obtained, namely primary and secondary data. Primary data were obtained from primary sources (such as the head of the central winning team for the United Development Party (PPP). Then secondary data obtained from findings of existed research.

This is descriptive research. Meaning, it makes observations on problems in a systematic way. This method is used in discussing the theory of Islamic populism referring to the facts that took place on the ground during the 2019 General Election

\section{DISCUSSION}

The results of research and analysis of research data on the factor of vote reduction are only limited to PPP in the situation of Islamic populism. The Islamic populism referred to in this study is the condition of the political narrative that was built in the 2019 election, which revolves around the issue of Islam. Where the growing campaign narrative is about who best represents Muslims or Islamic groups. However, in the midst of these conditions, it seems that it does not have a significant effect on PPP's vote acquisition in the 2019 Election. In addition, PPP is also known as an old political party such as PDIP and Golkar which should have been well established and experienced in navigating electoral battles.

\section{A. Factors in the Decline of PPP's Vote in the 2019 Election}

\section{A.1 Internal Factors of PPP Instability}

In general, perhaps we can see and identify PPP as a political party that has a mass base or political preference for the Islamic community. This cannot be seen far from the party symbol or logo, which displays the image of the Kaaba. Maybe philosophically, we can understand that PPP wants to represent itself as the big house of the Islamic community. Then when we refer to the articles of association and by-laws, PPP explicitly describes it as an Islam-based party. However, it should be noted that within the PPP body there are many backgrounds of Islamic groups which are one of the factors causing the internal PPP to be plagued with many problems.

According to Professor Endang Turmudi (2020) if we look back along the history of the Islamic political party in Indonesia, namely Masyumi. At first it was the largest Islamic party but, in its development, it also experienced internal instability which was marked by the release of various Islamic organizations within the body. This is what happened again in the PPP itself. It should be understood that PPP's internal instability has been ingrained during its development. We can see, for example, in the early stages of the formation of PPP (Endang Turmudi, 2020) This conflict occurred after the 1978 General Election in which MS Mintareja as the first general chairman was appointed and then replaced by Jaelani Naro due to external encouragement, namely from Suharto to try to dwarf PPP. Naro's leadership period is known to be closely related to the Soeharto government's intervention in the PPP. This conflict was strengthened when there was an attempt to pressure the NU group to leave PPP.

From these efforts a movement was formed to bring down Naro. After that, a narrative is presented to immediately conduct the congress. Then from this narrative a division was created in favor of the immediate convening of the congress, namely by the $\mathrm{NU}$ group and those supporting the 
postponement by the Perti, PSII and Parmusi groups (Nurdin, M. Amin, Ali Thaufan Dwi Saputra, 2019). The next conflict that occurred was when a rival DPP was formed initiated by "Group 18", which initially this group threw a "no-confidence vote" statement at Naro. In addition, the group also dismantled the United Development faction in the DPR. But in fact, according to Syamsyudin Haris's view, the movement of this group can be said to always fail because it does not get support from the government (Nurdin, M. Amin, Ali Thaufan Dwi Saputra, 2019). Another major conflict was present and had a very significant impact on the decline in vote acquisition in the general election, specifically the decline in vote acquisition for the 1982 general election.

This is an implication of the strong sentiment between NU and non-NU groups that has been built up in PPP internals and by Naro's controversial policies within PPP internals. For example, when Naro violently removed candidates with NU backgrounds. We can see that there are efforts to suppress and reduce NU's quota in the PPP nomination (M. Amin Nurdin, Ali Thaufan Dwi Saputra, 2019:89). The internal struggle between $\mathrm{NU}$ and PPP continued and this time became its climax and resulted in the exit of NU from PPP. This conflict and battle was very obvious when an NU kyai, namely KH. Achmad Siddiq Rais Am NU. Giving a fatwa that it is not obligatory to support PPP. Then $\mathrm{NU}$ also published a book with the title $\mathrm{NU}$ and Elections, which was written by Zuhdi Muhdlor. Where the book explains about the injustices that happened and were carried out by the PPP elite to NU. This had an influence on the results of the 1987 General Election (M. Amin Nurdin, Ali Thaufan Dwi Saputra, 2019:90).

Naro's actions during his tenure as PPP chairman accumulated to the point of ruining his political career when the momentum approached the second congress by monopolizing the committee and on the other hand, he felt he had the upper hand because he was running for vice president for the 1987 general election. His efforts to represent himself as cawapres considered as a form of resistance to the New Order domination. Then the aftermath for himself in PPP was not being reelected at Mukhtara II (M. Amin Nurdin, Ali Thaufan Dwi Saputra, 2019:92).

Ismail Hasan Metareum (Buya Ismail) was elected general chairman at the 1989 Second Congress. He served for two terms 1988-1994 and 1994-1998. This became the institutionalization phase of PPP in which Buya Ismail succeeded in reducing internal conflicts. Especially the frequent conflicts between NU and Parmusi. In addition, Buya Ismail succeeded in building social capital with the NU group and made NU figure Matori Abdul Jalil as
Secretary General of PPP (Nurdin, M. Amin, Ali Thaufan Dwi Saputra, 2019).

During the two periods under the leadership of Buya Ismail, PPP faced two general elections, namely 1992 and 1997. Both of them managed to reap positive results, namely an increase in the number of votes. Then a significant increase in the number of votes was during the 1997 general election. At that time, the community's critical attitude towards the New Order was developed, as well as the reform narratives presented by PPP. Then reinforced by the narrative "Mega-Bintang" where this narrative is a form of support present from Megawati sympathizers in the PDI who chose PPP. The narrative and volatility of PDI voters were also formed as a result of the PDI internal conflict between the Soerjadi and Megawati camps (M. Amin Nurdin, Ali Thaufan Dwi Saputra, 2019: 93).

Then in the early days of PPP reform, Hamzah Haz was led for two periods, namely 19982003 and 2003-2007. The challenges faced by PPP in the early days of reform were not only internal to the party, but also external. Namely, there are many Islamic-based parties present. Even the threats that were present were added to the issue of deflation by the former chairman of the PPP, namely Naro, who founded a new party called the United Party (PP). Because not a few of these parties took PPP cadres (M. Amin Nurdin, Ali Thaufan Dwi Saputra, 2019: 94).

PPP, which previously used the Bintang logo or symbol during the New Order, finally returned to using the Kaaba logo which was banned at Mukhtamar IV. With the change in the logo, it wants to rebuild its image and PPP positions itself as a victim of the New Order and also as an effort to change the image of the party formed by the New Order (M. Amin Nurdin, Ali Thaufan Dwi Saputra, 2019: 94).

Throughout the leadership period under Hamzah Haz PPP was again faced with internal conflicts, namely the conflict between Hamzah Haz and Zainudin MZ. The conflict that was suspected as a result was the policy to postpone the 5 th congress which should have taken place in 2003. Zainudin MZ then rejected the policy. The climax was when Zainudin MZ and his ranks left PPP and established PPP Reformasi. Despite the efforts of Hamza Haz to consolidate the ranks that came out, but to no avail (M. Amin Nurdin, Ali Thaufan Dwi Saputra, 2019: 95).

Then the Reformed PPP was transformed into the Reform Star Party (PBR). The implementation of the fifth congress, which had previously been postponed, was finally decided to continue and then Hamzah Haz was re-elected. During his second term in office, 2003-2007, PPP was again faced with internal conflicts. This can be 
seen when there is a movement to regenerate leadership even though the time has not yet come. This movement was initially triggered by the attitude of Zakarsih Nur, a PPP figure, who criticized all party policies which were seen as having many deviations, including being more opportunistic and seemed to have lost their ideology (M. Amin Nurdin, Ali Thaufan Dwi Saputra, 2019: 96).

The aftermath of this was Hamzah Haz dismissing PPP figures who were deemed not to follow and obey the party's rules. Among them are Lukman Hakim Saifuddin, Suryadharma Ali, Zarkasih Nur, Andi Ghalib, and Emron Pangkapi. Because they did not accept the decision, Surya and the ranks threatened to fire Hamzah back (M. Amin Nurdin, Ali Thaufan Dwi Saputra, 2019: 97).

After Hamzah retired, PPP was led by Suryadharma Ali. Surya served for two terms, namely 2007-2011 and 2011-2016. Surya realized the weakness of PPP's internal institutions, the impact of which was a loss for PPP. After being elected at the beginning of Surya's leadership period, he received opposition and demonstrations from mass groups who declared themselves as Pemuda Persatua. The demand is for Surya to accommodate the group in the structural arrangement of the management. With this, Surya finally tried to invite all cadres to unite. Another demand is to get an increase in votes in the 2009 General Election. Then to achieve this target, Surya invites cadres to be sensitive to issues related to improving the quality of education, alleviating poverty and responding to disasters (M. Amin Nurdin, Ali Thaufan Dwi Saputra, 2019: 97).

In the early days of Surya's leadership, he was seen as the ideal NU-Parmusi duo, but after only one year of his leadership, it was reported that there had been a split between Surya and Irgan. This is the impact of Irgan's refusal to agree and sign seven lists of legislative candidates. There were even rumors circulating that Irgan had been fired by Surya, but this was denied by PPP. The existence of internal PPP conflicts during the early days of Surya's leadership was also illustrated when a Parmusi figure in PPP, namely Bachtiar Chamsyah, stated that in the 2009 legislative elections, Parmusi cadres were freed to choose any political party. This is suspected by the existence of the PPP DPP policy to freeze the Chair of the East Java DPW Farid AlFauzi. He was frozen because he was deemed not to have fully supported Khofifah-Mujiono in the 2008 East Java gubernatorial election (M. Amin Nurdin, Ali Thaufan Dwi Saputra, 2019: 98).

During the time under Surya's leadership, PPP recorded poor results in the 2009 and 2014 elections. These results are suspected to be due to internal conflicts within PPP. For example, on the D day of the 2009 Legislative Elections, when the chairman of the PPP DPP Emron Pangkapi argued that Parmusi had distorted the votes. Based on these accusations, one of Parmusi's administrators, Lukman Hakim, reported Emron to the police, and Emron did the opposite. The conflict got hotter, when the results of the 2009 legislative elections for PPP decreased. Then was born an urgent movement to immediately hold an Extraordinary Congress (MLB). Surya alleges that this movement was led by Irgan, Arif Mudhatsir, Endin and Bachtizar Chamsyah (M. Amin Nurdin, Ali Thaufan Dwi Saputra, 2019: 100).

The conflict continued until close to the 2009 presidential election. It was seen that there was a division of support. The Surya camp supports SBY-Budiono, then the Irgan camp supports Prabowo. However, after a dynamic internal political process made Surya-Irgan reunite. Then decided to support Susilo Bambang Yudhoyono and Budiono. The names of the PPP Secretary General, Irgan Chairul Mahfiz and Bachtiar Chamsyah are not listed as the SBY-Boediono success team. Then after SBY won the presidential election, Surya got his share as Minister of Religion (M. Amin Nurdin, Ali Thaufan Dwi Saputra, 2019: 101).

Then in the second period, Surya, who was won at the VII Congress in Bandung, took $\mathrm{M}$. Romahurmuzy as Secretary General of PPP. This period is considered to be the moment of PPP's revival, because it is seen that PPP is ready to welcome the 2014 General Election. In addition, several PPP cadres who have jumped to other parties are predicted to return. However, this prediction failed, because PPP was again plagued by internal conflict problems after Mukhtamar VII (M. Amin Nurdin, Ali Thaufan Dwi Saputra, 2019: 102).

The conflict arose when the National Working Meeting (Mukernas II) in Bandung 7-8 February 2014, the majority of the Regional Management Board (DPW) rejected Surya's nomination as a presidential candidate. The mukernas issued several recommendations for presidential candidates that could be carried outside the general chairman of PPP, including: Syamsuddin (Chairman of PP Muhammadiyah); Joko Widodo (then Governor of Jakarta); Jusuf Kalla (senior Golkar politician); Din Jimly Assidiqie (former Constitutional Court Judge). (M. Amin Nurdin, Ali Thaufan Dwi Saputra, 2019: 103).

The conflict became more apparent when Surya was present during the grand campaign at the Bung Karno Stadium on March 23, 2014 to give support to Prabowo-Hatta. On this matter, several PPP elites gave negative opinions, such as Suharso Monoarfa who regretted Surya's attitude. Then from the Secretary General of the PPP at that time Romahurmuzy (Romy) and argued that the decision was only a personal act, not PPP's desire. Surya's 
arrival at the Prabowo-Hatta campaign also shows differences with internal parties, especially Romy as Secretary General who plans to form a coalition with the PDI-Perjuangan to support Jokowi-Jusuf Kalla. Firing each other and claiming the rightful management is the result of the conflict between Surya and Romy (M. Amin Nurdin, Ali Thaufan Dwi Saputra, 2019: 146).

Then the conflict escalated when Surya was named a suspect in a corruption case against the Ministry of Religion funds on May 22, 2014. This triggered Surya to be forced to resign by most of the PPP DPP administrators. Then also KH. Maimun as Chairman of the Sharia Council asked Surya to step down. However, Surya ignored these urges. Then Chozin Chumaidly as the Chairperson of the PPP Party Court on the basis that to immediately resolve the internal conflict, the VIII Congress must be carried out immediately (M. Amin Nurdin, Ali Thaufan Dwi Saputra, 2019: 146).

Then from each camp held a congress. Romy's camp held on 15-18 October 2014 in Surabaya, in which Romy was decided to become chairman. Then the Surya camp had plans to hold a Muktamar in Jakarta on October 30 and November 2, 2014 and did not accept the decision of the Muktamar for Romy's camp. However, two days before the Surya Muktamar was held, the Ministry of Law and Human Rights, Yassona Laoly, issued a Decree (SK) ratifying Romy's management (M. Amin Nurdin, Ali Thaufan Dwi Saputra, 2019: 147).

Even though the Decree of the Ministry of Law and Human Rights has been issued for Romy, Surya's camp continues to hold the VIII Congress in Jakarta. This congress is considered valid by Surya's camp because it was attended by 28 of the 33 DPWs considered to have fulfilled the quorum. Also added by Djan who explained that the congress of Romy's camp was invalid, and sued the results of the congress of Romy's camp to court (Nurdin, M. Amin, Ali Thaufan Dwi Saputra, 2019: 148).

If we look at the votes obtained by PPP, there is a negative trend, which is marked by a decrease in votes from election to election. This is suspected to be due to an internal conflict that has not been resolved. Then another aspect that became the cause was that there were many conflicting Islamic organizational backgrounds within PPP (M. Amin Nurdin, Ali Thaufan Dwi Saputra, 2019: 150).

The State Administrative Court (PTUN), on February 25, 2015 decided to grant the lawsuit from Djan's camp to Romy's management, and annulled the Decree of the Ministry of Law and Human Rights. Then the Romy camp and the Ministry of Law and Human Rights, on the same day, filed an appeal to the State Administrative High Court (PTTUN). As a result, the PTUN decision annulled the Romy camp's lawsuit, which was accepted by the PTTUN. The problem of dualism in the PPP body continued when the presence of the "Axis Rescue PPP" group, in January 2016. Those who stated that the results of the management were legitimate were the Djan camp (M. Amin Nurdin, Ali Thaufan Dwi Saputra, 2019: 151).

DPW and PPP elders asked for a request, then the government issued a policy of "back to the 2011 Bandung Mukhtamar" under the leadership of Surya (General Chair) and Romy (Secretary General) as a way out of the conflict. Active for 6 months. From the publication, it means that the results of the Mukhtamar for Romy and Djan's camp are considered invalid. The re-issuance of the 2011 Bandung Mukhtamar Decree, is a way to immediately conduct the "Mukhtamar Islah" by forming an Islah Council which includes representatives from Djan and Romy. However, Djan rejected this, then he sued President Jokowi, the then Coordinating Minister for Political, Legal and Security Affairs Luhut Binsar Panjaitan, and the Minister of Law and Human Rights Yasonna Laoly. (M. Amin Nurdin, Ali Thaufan Dwi Saputra, 2019: 152).

On 8-11 April 2016, the VIII Islah Congress was held at Pondok Gede Hajj Dormitory. However, Djan's camp refused and did not attend. In the implementation of the congress, Romy was elected by acclamation based on the results of deliberation not based on voting (M. Amin Nurdin, Ali Thaufan Dwi Saputra, 2019: 160).

Although plagued with unresolved conflicts, Mukernas II will still be held on 19-21 July 2017. It is also a PPP declaration to support Jokowi in the 2019 Presidential Election. The reason is that Jokowi's leadership has been very good for the benefit of the community, such as catching foreign fishermen in Indonesian waters, and several issuances of Healthy Indonesia Cards, Smart Indonesia Cards, infrastructure development (M. Amin Nurdin, Ali Thaufan Dwi Saputra, 2019: 162).

Due to the protracted conflict, Djan Farid as PPP General Chair as a result of the Jakarta Mukhtamar decided to resign and appointed the Acting General Chair, namely Humprey Djemat. According to Djemat, Djan's decision to resign because he felt he failed to resolve the dualism conflict that occurred. Then Djemat conducted mediation by meeting Islamic mass organizations such as the chairman of PBNU, Said Aqil Siroj. To be a mediator and do islah in the PPP body (M. Amin Nurdin, Ali Thaufan Dwi Saputra, 2019: 183).

Dimyati Natakusumah, Secretary General of PPP, Djan, decided to leave and join PKS. In fact, he is a member of the DPR RI PPP faction and has been introduced as a PKS candidate. Apart from the reasons for the ongoing conflict, Dimyati's move was 
because PKS represented PPP more like it was during the New Order.

According to Firman Noor, there are three things that cause conflict. First, weak leadership and the absence of a strong political patron to unite cadres. Second, the lack of internal ideological ties that lead to conflict. Third, there are parties from external PPP. (M. Amin Nurdin, Ali Thaufan Dwi Saputra, 2019: 163).

Then according to A. Bakir Ihsan's view that the problems that occur are influenced by four variables including the first external, many political parties are born which are slices of PPP such as the Crescent Star Party (PBB), the Indonesian Islamic Sarekat Party (PSII), the Nahdlatul Ummah Party (PNU). Second, the birth of Islamic parties whose bases are PPP masses, such as PKB (NU) and PAN (Muhammadiyah). Third, the presence of parties that have Islamic principles such as the Justice Party (PK) and the United Nations. Fourth, there was an internal conflict that gave birth to a splinter party, namely the Reform Star Party (PBR) (Ihsan, 2016)

The problematic conditions that occur in PPP are broadly in line with Mainwaring and Scully's opinion about the weak level of party institutionalization because one of them is the presence of one of the political actors, namely Djan in PPP, who does not want to recognize or legitimize Romy's leadership, and also refuses to do islah to create party system stability (Crotty, 2018: 340)

\section{A.2 External Factors}

\section{Weak Community Roots}

The strength of the party's roots in society or the strong relationship between voters and parties indicates a good level of party institutions. Voters choose their party based on ideology or based on work programs. Although the link between the program or the ideology of the voters and the party is not the only thing to create party stability, it is an important means for the party to take root in society. However, if the party during the election campaigns to withdraw the election based on broad personalism without looking at the party's ideology, then there will be weak party roots (Crotty, 2018: 353).

This institutional weakness was reflected in PPP during the 2019 General Election. Prior to the naming of Romy as a suspect in the case of buying and selling positions in the Ministry of Religion by the KPK, the party bearing the Kaaba symbol highlighted Romy's figure as a young and Islamic figure with the aim of being able to win votes from millennials and maintain a sound base. traditional (Rachman, 2019).

Romy's figure is featured in PPP advertisements on television before breaking the fast, with the appearance of young Islamic youth, namely a turban around the neck, white shirt, jeans, and without a skullcap while giving a message on the theme of Ramadan, (Kumparan.com, 2018) is common for weak party institutional systems. As in some old and established democracies, parties had strong roots in society before the advent of modern mass media, especially television. In Western Europe, working-class parties integrate workers into the political system and become the basic source of identity. On the other hand, before the weak institutionalization of television became an important media for parties, political figures appeared while giving messages (Crotty, 2018: 386)

It seems that PPP's long history in Indonesian politics does not make it have strong roots in society, because internally it is always plagued with endless conflicts. Not only that, during the mass reformation, two former PPP general leaders were involved in corruption cases, namely Surya and Romy. This seems to be one of the voter evaluations. Voters may think that PPP is no longer in accordance with Islamic values because of the arrest of former PPP leaders. Or according to Huntington's view that weak institutions are characterized by the loss of party value to actors within the party (Crotty, 2018: 357)

After the case of Romy's arrest, PPP seemed to be in chaos, because the figure who had been featured in the media and became the party's representative as well as the general chairman was caught in a corruption case. After Romy's arrest, PPP was then more dominant in selling a number of ulama or Kyai-Kyai who were in PPP with the tagline "the party of the ulama," "let's vote for the Kaaba" and featuring figures like KH. Syukron Makmum, KH. Idham Chalid, KH. Maimoen Zubair. This also proves that the institutional level of PPP is not working well, and is in line with Mainwaring and Scully's view that one of them is with a personalistic party.

Fragmentation of Islamic Political Election 2019

In recent years, the Islamic political narrative has been very strong. It is then that the voice of the Islamic community or politics in the name of Islam becomes the main target and main strategy for the party to gain votes. However, it should be noted that the fragmentation of the Islamic political narrative in society occurred in the 2019 General Election. To find this out, we need to understand first from a series of 212 mass action movements, which then continued until an alliance or group was created on behalf of the alumni of the movement (Fata, 2018: 335).

This movement was originally present because of the demand to try Ahok or Basuki 
Tjahyaja Purnama for the offense of blasphemy. This movement was initiated by the Islamic Defenders Front (FPI) chaired by Rizieq Shihab, with the support of a group on behalf of the MUI Fatwa Guard National Movement (GNPF-MUI, now transformed into GNPF Ulama). Such as Najib's view that groups such as the FPI and GNPF are typologies of neo-revivalist Islam that exist to fight for religion in social, economic and political life. The first achievement of the birth of this movement was the imprisonment of Ahok and his defeat in the 2017 DKI Pilkada (Fata, 2018: 335).

Then this group showed its strength, namely the results of the GNPF Ulama' ijtima' which determined the pair of president and vice president. This group clearly delegates its representatives, namely the revivalist group, as vice president to accompany Prabowo. Names such as Salim Segaf AlJufri and Abdul Somad who have a tendency to conservative Islam, his name came to the surface as a vice presidential candidate for 2019. Although in the end this did not materialize, because Prabowo was paired with Sandiaga Uno. This group remains in the ranks of Prabowo-Sandi supporters (Fata, 2018)

The existence of this neo-revivalist Islamic group has created a counter-narrative, namely plural Islam or moderate Islam represented by NU, which takes a neutral stance and does not take a stance to participate in moving mass actions on the streets like the neo-revival groups. These groups in the 2019 election became targets for political parties as well as for presidential and vice presidential candidates. We can see this from the efforts of the presidential and vice presidential candidates who collaborate with Islamic parties and influential scholars in Islamic society. For example, the Jokowi-Ma'ruf pair took PKB and PPP, then Prabowo-Sandi took PKS, PBB, and PAN (Wasisto Raharjo Jati, 2013)

According to Abdil Mughis et al.'s view, the exclusive narrative of Islam that is related to the agenda of Islamization and leadership issues creates a counter-narrative of pluralist Islam to minimize the movement of radical Islamic groups. With the support of the Populist-Nationalist group and the Islamic pluralist group, the government at that time introduced various policies to limit other political Islamic groups. For example, the birth of the policy to ban "anti-Pancasila" mass organizations and the issuance of Perppu No. 2 of 2017 regarding changes to the law. 17 of 2013 concerning mass organizations. From this, we can see that the Islamic political narrative is equally used by both parties, both neo-revivalist Islamic groups and pluralist or moderate Islamic groups (Fata, 2018: 340)

Jokowi's decision to partner with Ma'ruf Amin is a manifestation of efforts to reduce the space for neo-revivalist Islam. Apart from being an effort to protect himself, Ma'ruf is an important figure throughout the implementation of the political agendas of the Muslim group, who has a background as a former chairman of the MUI who is also Rais 'Aam Syuriah PBNU. The peak of the political agenda played by Ma'ruf was when he issued the MUI fatwa regarding blasphemy committed by Ahok (Fata, 2018: 341)

The existence of $\mathrm{NU}$ as a representation of a pluralist group that is neutral towards mass action movements is the main attraction for both parties to cooperate. This is reinforced by the claim that $\mathrm{NU}$ has 60 million members which are considered to be an important weapon to win the election contestation. Then the divisions that occur in Indonesian Islamic politics are increasingly apparent when Jokowi's camp builds an oderat Islamic narrative or 'Islam Nusantara'. Which has the meaning of Islam which can be in accordance with or in line with the principles of Pancasila, the culture of the Archipelago, and Bhinneka Tunggal Ika (Fata, 2018: 341).

It is interesting to see based on the results of an interview with Achmad Baidowi Wasekjen PPP, that PPP has a composition of 50 percent of its board members are NU citizens, and in the 2019 election it has the main target of NU people, because it has a larger demographic. Also, Nahdiyin residents still have a large voting influence, although not all votes go to PPP (Achmad Baidowi, 2020) This statement is also shared by Professor Endang Turmudi, an LIPI researcher with an NU background. He even served as Secretary General of PBNU in 2004-2009. That what happened at PPP was because it was always plagued with various problems of internal conflict between Islamic groups and such as the Masjumi problem, which often resulted in internal conflicts. Then if it is historically drawn that the NU conflict has also occurred in Masjumi's body, until at its peak NU came out and founded its own party (Turmudi, 2020)

Likewise, what is currently happening with PPP, that historically, NU people have had a bad history in PPP. Starting with Suharto, who had a phobia of Islam, pressured NU people in the PPP body to leave. Until the appointment of John Narrow as chairman of the PPP to reduce the political movement of the NU people. So there was an incident of undermining PPP by NU people. Then the NU people who are now in PPP are only a small part.139 In addition to the current development, the NU people tend to shift their election to PKB as an Islamic party based on the votes of the NU mass organizations. 


\section{B. Contradicting Islamic Populism and PPP in the 2019 Election}

A significant aspect of elections is the electorate. Therefore, political parties flocked to be able to get a lot of votes from voters. In the study of political science, voter behavior is a manifestation of political actions or decisions made by voters. In the background of this research, it has been explained that the political narrative of Islamic populism is very strong. But the question is whether this has an electoral impact for PPP and voters to be carried away by the dominant political narrative of Islamic populism. Plus, according to the latest 2010 statistics from the Central Statistics Agency (BPS) that the number of Indonesian Muslims is almost 88 percent, then 1 percent Buddhist, 2 percent Hindu, 3 percent Catholic, and 7 percent Protestant. This may be a great opportunity for the political preference of the Muslim community towards the tendency to choose Islamic parties. But what happens in society is that secular parties such as PDIP, Golkar, and Democrats can attract a large proportion of Islamic voters. On the other hand, non-Muslim voters such as Protestants, Catholics, Hindus and Buddhists tend to choose secular parties. This means that broadly speaking, if the number of non-Muslim voters increases, the secular parties will become stronger (Mujani, Saiful, R. William Liddle, 2019: 105).

Looking back at the 1999 elections, 57 percent of PDIP and Golkar voters were Muslim. Then 45 percent of Muslim voters chose the Golkar, PDIP, and Democrat parties in the 2004 Legislative Election, then 19 percent chose parties based on Islamic organizations, namely PKB (Based on Nahdatul Ulama) and PAN (based on Muhammadiyah); and 18 percent voted for the two largest Islamic parties, namely PPP and PKS. Then if these numbers are added up, the number of voters for nationalist parties from among the Muslim community is greater than the number of Muslim voters who choose Islamic parties and are based on Islamic organizations (Mujani, Saiful, R. William Liddle, 2019: 105).

Then in the 2009 legislative elections, almost 60 percent, the major secular parties namely PDIP, Golkar, Democrats, Hanura, and Gerindra were elected by Muslim voters. This pattern was also repeated in the 2014 election, coupled with the political preference of non-Muslims not to vote for parties that have an Islamic background or have a mass base of Islamic organizations (Mujani, Saiful, R. William Liddle, 2019: 105). Then in the 2019 elections a similar pattern was repeated, with the majority Muslim voters choosing political parties. Secularists in order from highest to lowest are PDIP, Gerindra, Golkar, Nasdem, and Democrat (Indikator Politik Indonesia, 2019).
This happened because nationally the Indonesian people did not have a balanced composition between religions, ethnicities or races, therefore it did not have much impact on the national vote in the 2019 Election. First, it can be seen, for example, that the results of the survey on the electability level of the presidential candidate for President Jokowi did not experience a decline., even experienced an increase of $9 \%$ and Prabowo, who is close to the Muslim political elite, stagnated (Fernandes, 2018:8)

Second, if the narrative of Islamic populism is measured by participation in the 212 action movement, there will be a distribution of votes for the two presidential candidates. Third, the votes of the participants of the 212 action movement were spread out, even the PDIP party that supported Ahok's candidacy got $16.6 \%$. Also spread to other Nationalist parties such as Golkar $10 \%$. However, as many as $45 \%$ of the participants' votes were spread over Gerindra 29.1\% and PKS 13.4\%. (Fernandes, 2018:8).

Then the narrative of Islamic populism or the influence of religious issues in the 2019 elections had no impact on PPP, like a fire that was far from the grill because the people who built the narrative were from different group backgrounds. Where the difference referred to here is the political preference between groups that support Jokowi's government and the opposition. This is in line with the findings of an interview with the Chairman of GNPF Ulama Yusuf Muhammad Martak with the media Tirto that he will only support parties that do not support religious blasphemers including PKS, PAN, Gerindra, and PBB (Sumandoyo, Arbi, 2018).

Then added to the findings with the results of the researcher's interview with the Wasekjend PPP Achmad Baidowi (June 12, 2019):

\footnotetext{
"Those who carry the thick spirit of Islamic populism are the average opposition to the government. So when the party in the government is considered the enemy. Various rumors were made, that PPP supported Ahok even though it didn't. There is not a single official letter stating that PPP supports Ahok. Supporting Ahok is Djan Farid's PPP. The official PPP, the legitimate PPP doesn't support anyone in the second round. Only the first round supported Agus Harimukti Yudhoyono-Sylviana Murni. After that there is no more."
}

\section{The Ineffectiveness of Islamic Populism for PPP in the 2019 Election}

Having previously discussed that there has been a division in the political narrative of Islamic populism both in community groups and political actors or politicians, this time we will discuss the ineffectiveness of the Islamic populism narrative for 
PPP. In general, based on the aggregate comparison, the votes obtained by political parties based on Islam or based on Islamic organizations have decreased from the 2014 general election of 31 . $25 \%$ to $29.26 \%$ of the 2019 election. This means that from the findings there has been a shift or evaluation of voters in Islamic parties.

Although in some survey results such as LIPI that respondents tend to use religion as a consideration of political choices, it does not seem to have an impact on the selection of legislative candidates. This can be seen from the votes of the nationalist parties which failed to be matched by the votes of the Islamic parties. In the opinion of Djayadi Hanan, this happened because in the 2019 election there was a multipolar political polarization, namely there was quite a lot of competition or political party battles (LIPI, 2019).

Then based on the results of the Political Indicator Exit Poll, where the majority of respondents have an Islamic background, the voters tend to choose the party mostly based on the first reason, the program being implemented or promised. Second, based on the choice of family members. Third, based on the influence of the campaign, through banners, marches, or advertisements on TV. Fourth, most fight for the little people. While the reason or tendency to choose a party based on religion or the most fighting for religion is in the eighth position out of thirteen. Then the reason for choosing a party based on the recommendation of a kiai or religious leader is on the other side of thirteen (Indikator Politik Indonesia, 2019).

In addition, according to the results of a survey conducted by the Center for Strategic and International Studies (CSIS), it shows that there has been a migration of political choices from those who previously chose Islamic parties in the 2014 elections to nationalist parties in the 2019 elections by $20.7 \%$. Larger than the migration of nationalistbased parties to Islam-based parties in the 2014 Election to the 2019 Election of 5.7\%.150

Although religion is one of the reasons for political choice in parties, this tendency also explains that the choices of Islamic society are also spread to secular parties such as PDIP, Golkar. In addition, religious minorities or non-Muslims have a solid voting pattern for secular parties, and almost no one chooses an Islamic-based party. This means that if the number of non-Muslim communities increases, the votes of secular parties will be stronger. This means that although religion has an influence on political choices, it is limited in nature (Fernandes, 2019).

It also explains the people's choices to the presidential and vice-presidential candidates. That the main reasons for voters in the 2019 election are simplicity, firmness, and being able to bring about change. The point is that choice is more about looking at the quality of candidates (Mujani, Saiful, R. William Liddle, 2019). Then if we look at the results of the recent elections. For example, in the first round of the 2004 elections, figures representing Islamic groups or santri sects such as Amien Rais or Hamzah Haz even though their vote base was very strong from Muslim voters, Muslim votes were also spread to Megawati, Wiranto, and Yudhoyono. Even if it is measured from the flow of religiosity or the group of students, the vote is greater for Yudhoyono or Wiranto than Amien Rais or Hamzah Haz (Fernandes, 2019).

Then in the second round of the 2004 election, although Megawati collaborated with Hasyim Muzadi, who is the chairman of NU, and is the largest Islamic organization in Indonesia, it did not have a significant impact on Megawati's vote. Because it turns out that the proposition of Muslim voters is bigger for Yudhoyono-Kalla. Then in 2009 the proportion of Muslim voters to Megawati Prabowo was smaller than those to YudhoyonoBoediono. This also happened in the 2014 election that the proposition of Jokowi-Kalla voters was smaller than that of Prabowo-Hatta voters (Mujani, Saiful, R. William Liddle, 2019: 109)

In the 2019 election, he also explained that the political choices of the people based on Islam were the highest percentages obtained by PDIP, Golkar, and Gerinda. Then followed by the Islamic party, namely PKB. Several other Islamic parties, such as PKS, PAN, PPP, are behind secular parties such as the Democrats (Fernandes, 2019).

\section{CONCLUSION}

Based on the findings of the researcher, the failure of PPP in gaining support for Islamic populism is a problem of the weak level of party institutionalization, the division of political Islam, the incompatibility between Islamic populism in the 2019 election and PPP, and the pattern of voter behavior that tends not to take religion as a political choice consideration. consistent. The level of strong institutionalization is measured from four points, namely the pattern of strong competition between parties or the aggregate of a party's vote from election to election is not large, the attachment between the community and parties, political actors legitimizing political parties, not personalistic.

PPP itself gets a percentage that consistently tends to decrease. The 1999 election vote was 10.71 percent, the 2004 election was 8.16 percent, the 2009 election was 5.33 percent, the 2014 election was 6.53 percent, the 2019 election was 4.59 percent. This is one of the impacts of PPP's internal conditions which have experienced many problems, 
such as elite conflicts due to the struggle over the general chairman position, then also the problem of losing party values, namely Islamic values such as corruption.

Plus, the PPP's political strategy so far has no new breakthroughs. For example, regarding the target of support in the election, based on the results of the researcher's interview with Achmad Baidowi as the current Deputy Secretary General of PPP. In the 2019 election, it only focused on Islamic groups or the NU mass organization. Then before the general chairman figure was arrested in a corruption case, the campaign pattern or approach to the community was used more through advertisements on TV and still selling Romy's personalism. If TV media is still a significant target for gaining public votes, what should be sold is about the achievement of the party's work program during the previous period, or what breakthroughs have been carried out and have benefited Muslims.

Unfortunately, before the election, the figure who had been sold, namely the general chairman Romy, was actually arrested for a corruption case. This also increases the negative perception of PPP. Even based on the results of the survey agency's predictions, PPP is threatened not to pass the parliamentary threshold (parliamentary threshold of 4\%). Although PPP is the only Islamic-based party based on the AD ART contained in the Party, it also has the threat of gaining votes from external parties. Namely competition from parties whose vote base or target is Muslims such as PKB, PKS, PAN.

Then PPP during the 2019 election ahead of the analysis based on research data findings, did not focus on approaching or building a strong network of Islamic groups that carried out the Islamic defense action movement who called themselves 212 alumni. Whereas if PPP does image itself as a big house for Muslims, it must accommodate the interests of the group. Then form or consolidate other Islamic parties to unite. Even long before the 2019 election, in 2017 the PPP declared to support Jokowi in the 2019 election, who was branded by Islamic populism as a leader who supports blasphemers, and enemies of Muslims. Even though these were the times when the narrative of Islamic populism was at its strongest.

Although the findings show that religion as a consideration for political choices is limited and the people who participate in the movement spread their votes to secular parties, it is also found that the data has an important electoral effect for PKS and Gerinda. From the beginning, he was close to the group, until rumors circulated that he would nominate a vice president from the group's proposal.

Then also the effects of dualism or the conflicts that occurred in PPP contributed to a bad impact on the party's image. Namely, during the 2017 DKI Pilkada where this was one of the momentums for the rise of Islamic populism narratives. PPP was reported by several media to support the candidate pair Ahok-Djarot in which Ahok is a suspect in the case of blasphemy. Although according to the results of the researcher's interview with Achmad Baidowi as the current Secretary General of PPP, those who declared their support for Ahok at the PPP management office in the second round of the 2017 Pilkada were from the Djan Farid group who were considered illegitimate management. He admits that this adds to the bad perception of PPP in the Islamic community. Although it is not a legitimate support from PPP, the researcher sees this as a result of dualism and internal conflicts that occur.

Then it turns out that the high level of Islamic religiosity of the community so far is not in line with the decision of the wider community to bring Islam into the political sphere, fully support Islamic parties and support candidates who most prioritize the interests of Muslims at large. Because it turns out that if the size of Islamic populism is the people who join the movement to defend Islam and the like. There was a finding that the voices of the people who participated in these activities in the 2019 General Election were spread to other parties and even to the PDIP which was branded as the biggest enemy of Muslims. Plus secular parties are approaching and trying to get votes from all walks of life and backgrounds including Muslims. Gerindra is a form of secular party that has an electoral effect for Islamic populism groups. 


\section{REFERENCES}

\section{BOOK}

Buchari, Sri Astuti. 2014. Kebangkitan Etnis menuju Politik Identitas". Jakarta: Yayasan Pustaka Obor Indonesia.

Fathurahman, Pupuh. 2011. Metode Penelitian Pendidikanan andung: CV Pustaka Setia.

Geertz, Clifford. 2014. Agama Jawa: Abangan, Santri, Priyayi Dalam Kebudayaan Jawa,. Depok: Komunitas Bambu.

Hadiz, Vedi R. 2016. Islamic Populisme in Indonesia and the Middle East. Hadiz, Cambridge University Press.

Ihsan Dr. A. Bakir. 2016. Ideologi Islam dan Partai Politik: Strategi PPP dalam Memasukan Nilai-Nilai Islam ke dalam Rancangan UU di Era Reformasi. Ciputat: Orbit Publishing Jakarta.

Kadir, A. Gau. 2014. Dinamika Partai Politik Indonesia. Jurnal Sosiohumaniora, Volume 16 No. 2 (Juli).

Katz, Richard S. dan William Crotty. 2018. Handbook Partai Politi (Bandung: Nusa Media).

Muddle, Cas dan Cristobal Rovira Kaltwasser. 2017. Populisme a Very Short Introduction. New York: Oxford University Press.

Mujani, Saiful, R. William Liddle, dan Kuskridho Ambardi. 2019. Kaum Demokrat Kritis: Analisis Pemilih Indonesia sejak Demokratisasi,. Jakarta: Kepustakaan Populer Gramedia.

Nurdin, M. Amin, Ali Thaufan Dwi Saputra, Adi Prayitno. 2019. Prahara Partai Islam:Komparasi Konflik Internal PPP dan PKS. Jakarta: Yayasan Pustaka Obor Indonesia.

JOURNAL AND ARTICLE

Djuyandi, Yusa dkk,. 2019. Strategi Kampanye Sudrajat-Syaikhu Mendapatkan Dukungan Masa Populisme Islam dalam Pilgub Jawa Barat 2018. JPI: Jurnal of Political Issues, Fakultas Ilmu Sosial dan Ilmu Politik, Universitas Bangka Belitung, Vol 1, No. 1 (Juli).

Francis Fukuyama. 2019. "Indentity politics: The Demand for Dignity and the Nation State'sFuture," diakses pada 14 September, pukul 2:10 WIB dari(melalui link http://www.erstestiftung.org/en/francisfukuyama-identity-politics/)

Jati, Wasisto Rahardjo. 2017. Trajektori Populisme Islam di Kalangan Kelas Menengah Muslim Indonesia. Jurnal Prisma, Vol. 36, No. 3.

Muljana, Slamet. 2012. Kesadaran Nasional; Dari Kolonialisme Kemerdekaan(Yogyakarta: LKiS,)
Pamungkas, Arie Setyaningrum dan Gita Octavia. 2017. Aksi Bela Islam dan Ruang Publik Muslim: Dari Representasi Daring ke Komunitas Luring. Jurnal Pemikiran Sosiologi Volume 4 No. 2 (Agustus).

Prayogi, Irfan dan Fernanda Putra Adela. 2019. Populisme Islam dan Imajinasi Politik dalam Pilkada DKI Jakarta 2017. POLITEIA: Jurnal Ilmu Politik, Vol 11 (Februari).

Sianipar, Imelda Masni Juniaty. 2015. Strategi Pemimpin Populis Baru Indonesia Mencapai Kekuasaan. Jurnal Sociae Polites, Fakultas Ilmu Sosial dan Ilmu Politik Universitas Kristen Indonesia, Vol 16, No. 01(JanuariJuni).

\section{ESSAY}

Yeby Ma'asan Mayrudin. 2012. "Transisi Demokrasi dan Perilaku Partai Islam: Studi tentang Kemerosotan Perolehan Suara PPP Pasca Orde Baru," (Skripsi S1 Fakultas Ilmu Sosial dan Ilmu Politik, Universitas Islam Negeri Jakarta). 